\title{
民間および自治体土木技術者の 評価・育成に関する調査分析
}

\author{
野口 好夫 1 鈴木 弘司 2 ・清水 千尋 3 \\ 1正会員 建設技術マネジメント研究所（†450-0002 名古屋市中村区名駅四丁目25番17号） \\ E-mail: y.noguchi.tm@qc.commufa.jp \\ 2正会員 名古屋工業大学 大学院工学研究科 准教授 (†466-8555名古屋市昭和区御器所町) \\ E-mail:suzuki.koji@nitech.ac.jp \\ 3正会員 三重県桑名建設事務所（干511-8567 三重県桑名市中央町5丁目71番地） \\ E-mail: shimic01@pref.mie.jp
}

\begin{abstract}
本研究では土木技術者の評価・育成の現状把握を目的に企業・自治体を対象としたアンケート調査を実 施し, 土木技術者に求められている評価・育成の仕組みに対する現状や課題の整理を行った。 その結果, 中小規模ゼネコンでは評価項目を決めて技術者評価を行っている割合が低いなど建設会社，建設コンサル タントといった業種・業態による違いがあること, 技術者に対する評価項目が業務経験年数や業種・業態 によって異なることがわかった，技術者育成の現状については，中小規模ゼネコンの約半数がOJTを制度 化しておらず，キャリアプランを考える機会をあまり与えず，さらにはキャリアパス自体を作成していな い傾向が強いこと，また，民間では資格取得支援をする割合が高い一方，自治体ではその割合が低いこと などがわかった。
\end{abstract}

Key Words : Civil engineers, evaluation, human resources development, questionnaire

\section{1. はじめに}

戦後，高度成長期に多くの社会資本が整備され，社会 資本全体の高齢化が急速に進行する中，近年，土木技術 者の業務は，既存施設の効率的な維持管理を主体とする 内容に変化してきた．他方，逼迫した財政状況のもと， 予算規模が縮小されるなか, 2008 年の世界金融危機を 契機に民間建設投資が大きく落ち込むことで建設産業の 経営環境は大変厳しいものとなっている。このような状 況下，ここ数年，団塊世代の土木技術者の大量離職，経 営不振による新人技術者の雇用数抑制, 若年技術者の早 期離職などが問題となっている. 建設産業はものづくり 産業であるため, それを支える人材の確保が重要となる が，これらの問題により，技術者不足や技術力低下，技 術者の育成や技術の伝承が難しくなっているといえる.

また，閉塞感が漂う国内市場の反面，アジアをはじめと する新興国経済の成長が堅調であることから，企業の海 外進出の機会が増加してきている. しかしながら, 従来 の土木技術者に対する評価は，これらの環境変化に対応 できておらず，まずは現状に対して求められる技術力を 整理し，技術者を適正に評価するための指標を作成する ことが急務といえる.
そこで，本研究では，土木技術者の評価・育成の現状 を把握するために，企業・自治体を対象としたアンケー 卜調査を実施した. アンケートから現在の土木技術者に 求められている, 評価・育成の仕組みに対する現状や課 題の整理を行った.

\section{2. 民間企業における土木技術者評価に関する現 状分析}

\section{(1) 企業アンケートの概要}

企業アンケートの概要を表-1 に示す. 本アンケート では，人事管理・営業・技術の部門別や従業員数別など の視点から結果を考察するため，属性に関する質問項目 を設けたが，部門別で分類すると回収したデータ数に大 きくばらつきがあった．よって本研究では, 部門別の詳 細な分析は行わず，建設会社の従業員数 100 人以下(以 下，中小規模ゼネコン), 101 人以上(以下，大規模ゼネ コン)，及び，建設コンサルタント(以下，建設コンサル)

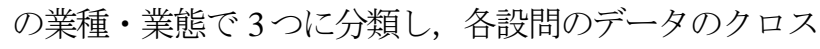
集計を行った. なお，中小企業基本法において，建設業 では, 常時活動する従業員の数を 300 人以下とする会社 
を中小企業と呼称しているが，建設業界では中小零細企 業の割合が高いため, 本集計では, 回答企業数のバラン スを考慮し，従業員数 100 人を境界とし，建設会社を分 類することとした．また，同一会社内の複数部門が回答 した場合も存在するが，回答内容が異なっていたことか ら，それぞれを別の回答として扱っている．部門ごとの 詳細な分析については今後の課題とする.

\section{（2）民間企業における土木技術者評価の現状}

土木技術者に対する評価項目の有無を図-1に示寸.

これより，中小規模ゼネコンでは 88\%，大規模ゼネコ ンでは 89\%，建設コンサルでは 92\%の企業が技術者を評 価しており，中でも大規模ゼネコンは 65\%，建設コンサ ルは 78\%の企業が評価項目を決めていることがわかる.

中小規模ゼネコンでは評価項目を決めて評価を行ってい る割合が 26\%と低く，大規模ゼネコンや建設コンサルの 半数以下であることがわかる.

図-1 より，評価項目を決めて評価を行っていると回 答した企業に対して，「評価方法」，「評価の仕組みの 周知」，「評価が会社の経営に役立っているか」につい ての質問をし，それぞれ集計した結果を図-2，図-3，図4に示寸.

図-2 より，中小規模ゼネコンでは 25\%，大規模ゼネ コンでは 48\%，建設コンサルでは，71\%の企業が社内規 定を有し，評価制度を確立していることがわかる，よっ て，建設会社では従業員数が多いほど社内規定が確立さ れており，建設会社より建設コンサルの方が社内規定が 確立されていることが伺える.

図-3 より, 中小規模ゼネコンでは 56\%, 大規模ゼネ コンと建設コンサルでは $82 \%$ 企業が全社員に評価の仕 組みを周知させていることがわかる. よって中小規模ゼ ネコンに比べ大規模ゼネコン・建設コンサルでは評価の 内容が社員に対して開放的であるといえる.

図-4 より，中小規模ゼネコンと建設コンサルでは 100\%，大規模ゼネコンでは 96\%の企業が，会社の経営 に評価が役立っていることがわかる．また，中小規模ゼ ネコンでは 7\%，大規模ゼネコンでは 15\%，建設コンサ ルでは 27\%の企業が評価をすることが会社の経営に非常 に役立っていることがわかる．よって，土木技術者への 評価は重要であり, 建設会社では従業員数が多いほど評 価が経営に非常に役立っており, 建設会社より建設コン サルの方がさらに評価が経営に役立っていると考えられ る.

\section{（3）業種・業態別の技術力評価に関する重みの違い}

図-1 より, 評価項目を決めて評価を行っていると回 答した企業に，どのような技術力が評価されているかを 把握するため, 評価項目について質問し, 各業務経験年
表-1 企業アンケート概要

\begin{tabular}{|c|c|}
\hline $\begin{array}{l}\text { アンケート } \\
\text { 実施日 }\end{array}$ & 平成23年10月 1 日～10月31日 \\
\hline 調査対象 & $\begin{array}{l}\text { 愛知県内の建設会社315社(総合工事業者, 専門工事業 } \\
\text { 者), 建設コンサルタント } 55 \text { 社 (土木コン, 補償コン, } \\
\text { 地質調査, 測量), 計370社 }\end{array}$ \\
\hline 調査方法 & $\begin{array}{l}\text { ・各社に3部 (人事管理・営業・技術) ずつ送付 } \\
\text { •部門別に技術者評価・育成に関わる立場の人に回答 } \\
\text { してもらう }\end{array}$ \\
\hline & ・郵送配布・郵送回収 \\
\hline \multirow{6}{*}{$\begin{array}{c}\text { 主な } \\
\text { 調査項目 }\end{array}$} & $\begin{array}{l}\text { ·会社属性 (従業員数・回答者の部門) } \\
\text { • 評価 (評価の有無・23項目の重み) }\end{array}$ \\
\hline & $\begin{array}{l}\text { 23項目を5段階評価一1. 評価項目ではない・2. 全然評 } \\
\text { 価しない・3. あまり評価しない・4. まあ評価する・5. } \\
\text { 高く評価する }\end{array}$ \\
\hline & $\begin{array}{l}\text { 業務経験年数 (3分類) による評価の重み一若手 (入社 } 5 \\
\text { 年未満)・中堅 (入社 } 5 \sim 15 \text { 年 }(\text { 係長クラス }) \text { ・ベテラン } \\
\text { (入社 } 15 \text { 年以上 (課長クラス)) }\end{array}$ \\
\hline & ・育成 (OJT実施・資格取得協力の有無) \\
\hline & ・キャリアプラン \\
\hline & ・アンケートに関する感想 \\
\hline 回収状況 & 建設会社95社 (31\%)，建設コンサルタント39社 (69\%) \\
\hline
\end{tabular}
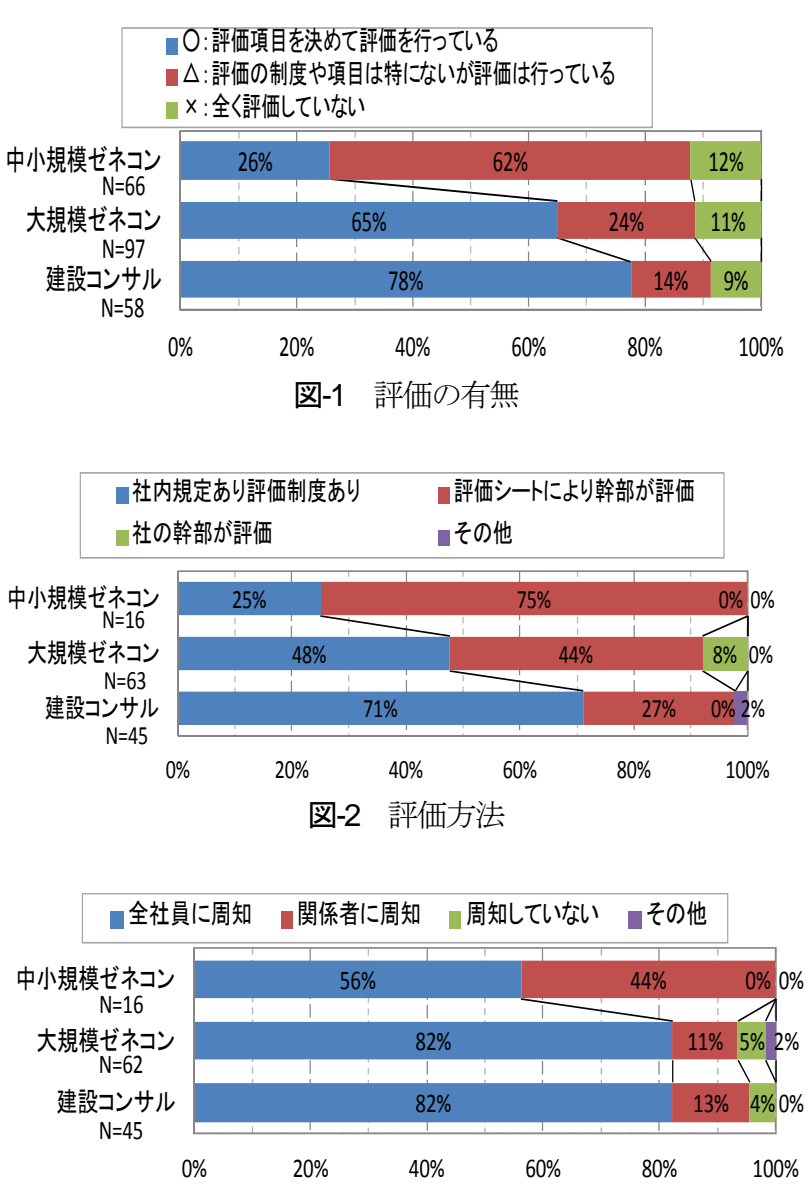

図-3 評価の仕組みを周知しているか

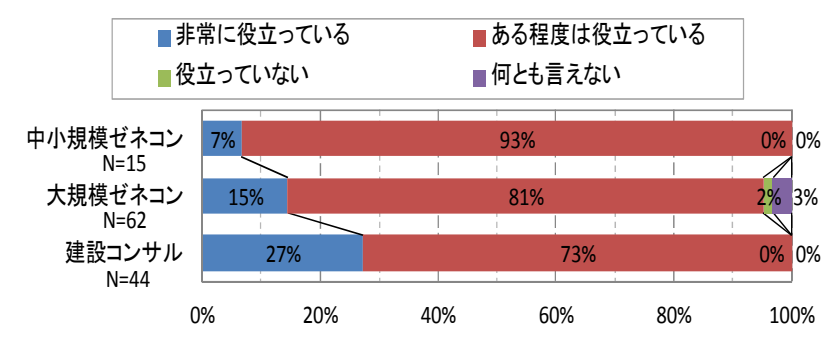

図-4 評価が会社の経営に役立っているか 
数別に, 評価項目ごとの平均值を集計した結果を図-5 に示す. 図の上段が若手，中段が中堅，下段がベテラン の結果を表す。ここでの平均值は「評価項目ではない 1」（表-1）を除き 2〜5 を用いて算出したものである. なお，評価項目は図-5 右表に示寸通り 23 項目用意した。

図-5より，どの業種・業態においても業務経験年数 が増えると平均值が高くなり, 業種・業態間の平均值の ばらつきが小さくなる傾向にあることがわかる．また， 評価項目 18，19 はどの年代でも平均值が 4 以上と高い ことから, 責任感や積極性は業務経験年数に関係なく求 められていることがわかる. 一方, どの業種・業態でも 評価項目 22 は平均 4 未満とあまり高く評価されていな いことがわかる.

評価項目ごとの特徵として，若手に着目すると，建設 会社ではどの規模においても評価項目 7，8，9の平均值 が 4以上と高いことから, 工程, 品質, 安全の各管理の 技術力が求められていることがわかる，一方，建設コン サルの若手では評価項目 2，14，15，19，20 の平均值が 4 以上でかつ建設会社より高いことから，分析解析力や 企画・改善意識, 説明力, 積極性などがより求められて いるといえる. さらに建設会社の従業員数別に着目する と, 評価項目 1，15，17，19 は従業員数が多いほど平均 值が高いことから，専門知識, 説明力, プレゼンテーシ ヨン能力, 積極性などといった対人的な項目が大規模ゼ ネコンで求められるといえる.

\section{(4) 分散分析による業種・業態別の技術力評価の重み の差異}

まず，年代別に着目し，各評価項目で業種・業態間の 技術力の評価値におけるばらつきを見るため，一元配置 の分散分析を行った. 若手の分散分析の結果を表-2, 中 堅の分散分析の結果を表-3, ベテランの分散分析の結果 を表-4 に示寸．なお，表-2 から表-4 において，統計的 な有意差のある評価項目の P-值の闌に黄色を付してい る.

表-2 より，評価項目 6 （技術的な企画・改善の提案）， 7，8，9（工程・品質・安全管理），17（プレゼンテー ション力），19 (積極性）が 5\%水準で有意であること が確認された.よって，これらの評価項目は若手におい て，業種・業態間で技術力の評価值に差があることがわ かる.

表-3 より，評価項目 1 (専門知識)，4（資格），5 (研究委員会・学会活動)，6（技術的な企画・改善の 提案）, 9 (安全管理力），11（技術営業力），17（プ レゼンテーションカ）, 21 (危機管理)，22（国際性） が有意であることが確認された. よって, これらの評価 項目は中堅において，業種・業態間で技術力の評価值に 差があることがわかる.

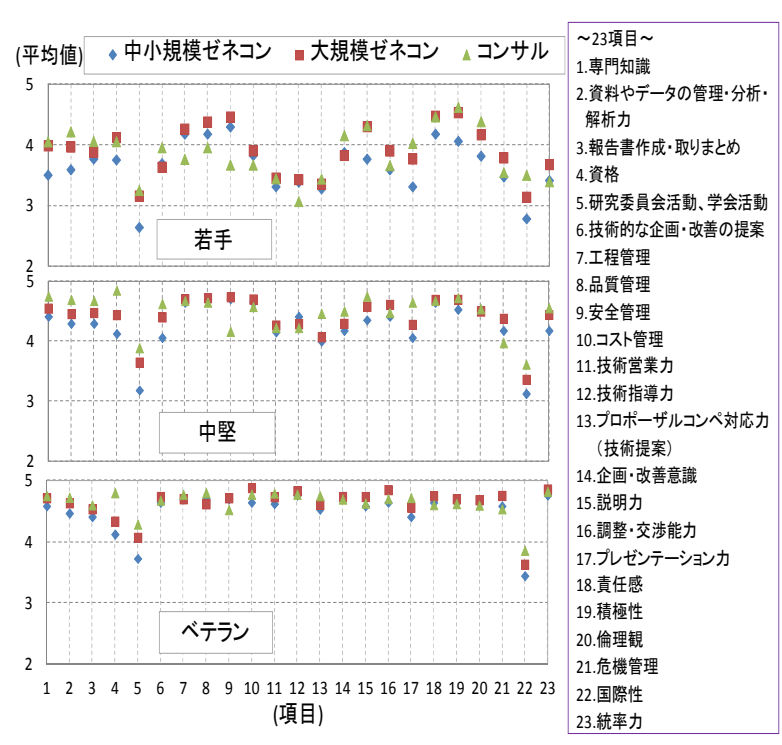

図-5業種別年代別の評価の重みの平均值

表-2 若手の一元配置分散分析(業種・業態別)

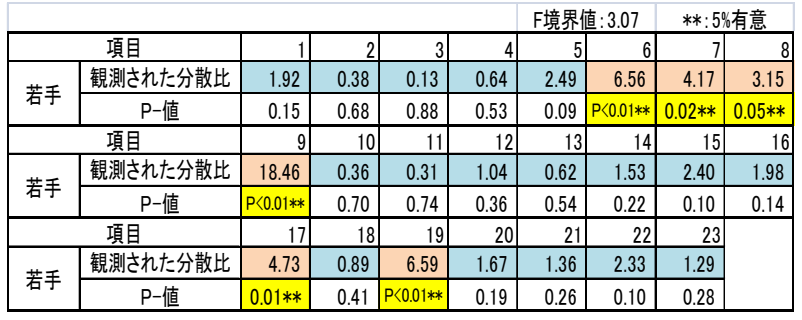

表-3 中堅の一元配置分散分析(業種・業態別)

\begin{tabular}{|c|c|c|c|c|c|c|c|c|c|}
\hline & & & & & & \multicolumn{2}{|c|}{ F境界値: 3.07} & \multicolumn{2}{|c|}{ **: $5 \%$ 有意 } \\
\hline \multicolumn{2}{|r|}{ 項目 } & 1 & 2 & 3 & 4 & 5 & 6 & 7 & 8 \\
\hline \multirow{2}{*}{ 中堅 } & 観測された分散比 & 3.08 & 0.23 & 0.46 & 7.41 & 7.35 & 6.93 & 0.02 & 0.03 \\
\hline & P-值 & $0.05 * *$ & 0.80 & 0.63 & $\mathrm{P}<0.01 * *$ & $\mathrm{P}<0.01 * *$ & $\mathrm{P}<0.01 * *$ & 0.98 & 0.97 \\
\hline \multicolumn{2}{|r|}{ 項目 } & 9 & 10 & 11 & 12 & 13 & 14 & 15 & 16 \\
\hline \multirow{2}{*}{ 中堅 } & 観測された分散比 & 13.13 & 0.69 & 4.11 & 0.70 & 2.45 & 1.59 & 2.91 & 1.69 \\
\hline & P-值 & $P<0.01 * *$ & 0.50 & $0.02 * *$ & 0.50 & 0.09 & 0.21 & 0.06 & 0.19 \\
\hline \multicolumn{2}{|r|}{ 項目 } & 17 & 18 & 19 & 20 & 21 & 22 & 23 & \\
\hline \multirow{2}{*}{ 中堅 } & 観測された分散比 & 4.04 & 0.26 & 0.76 & 0.14 & 5.32 & 3.58 & 0.86 & \\
\hline & P-值 & $0.02 * *$ & 0.77 & 0.47 & 0.87 & $0.01 * *$ & $0.03 * *$ & 0.43 & \\
\hline
\end{tabular}

表-4 ベテランの一元配置分散分析(業種・業態別)

\begin{tabular}{|c|c|c|c|c|c|c|c|c|c|}
\hline & & & & & & F境界 & 3.07 & $* *: 5$ & \\
\hline & 項目 & 1 & 2 & 3 & 4 & 5 & 6 & 7 & 8 \\
\hline & 観測された分散比 & 0.44 & 1.30 & 1.95 & 7.97 & 6.91 & 0.08 & 0.41 & 1.54 \\
\hline ערדה & $\mathrm{P}$-值 & 0.65 & 0.27 & 0.15 & $\mathrm{P}<0.01 * *$ & $\mathrm{P}<0.01 * *$ & 0.93 & 0.67 & 0.22 \\
\hline & 項目 & 9 & 10 & 11 & 12 & 13 & 14 & 15 & 16 \\
\hline & 観測された分散比 & 5.93 & 2.56 & 1.00 & 0.30 & 2.10 & 0.12 & 0.79 & 1.44 \\
\hline 人) & P-值 & $P<0.01 * *$ & 0.08 & 0.37 & 0.74 & 0.13 & 0.89 & 0.46 & 0.24 \\
\hline & 項目 & 17 & 18 & 19 & 20 & 21 & 22 & 23 & \\
\hline ベ- & 観測された分散比 & 0.71 & 0.63 & 1.62 & 1.39 & 3.54 & 3.03 & 0.07 & \\
\hline נרדאי & $\mathrm{P}$-值 & 0.49 & 0.53 & 0.20 & 0.25 & $0.03 * *$ & 0.05 & 0.93 & \\
\hline
\end{tabular}

表-5 中小規模ゼネコンの一元配置分散分析(年代別)

\begin{tabular}{|c|c|c|c|c|c|c|c|c|c|}
\hline & & & & & & \multicolumn{2}{|c|}{ F境界値: 3.17} & \multicolumn{2}{|c|}{$* *$ : $5 \%$ 有意 } \\
\hline \multicolumn{2}{|r|}{ 項目 } & 1 & 2 & 3 & 4 & 5 & 6 & 7 & 8 \\
\hline 中小規模 & 観測された分散比 & 18.45 & 9.97 & 6.30 & 0.68 & 1.29 & 14.45 & 7.39 & 7.17 \\
\hline ゼネコン & P-值 & $\mathrm{P}<0.01 * *$ & $\mathrm{P}<0.01 * *$ & $P<0.01 * *$ & 0.51 & 0.28 & $P<0.01 * *$ & $P<0.01 * *$ & $P<0.01 * *$ \\
\hline \multicolumn{2}{|r|}{ 項目 } & 9 & 10 & 11 & 12 & 13 & 14 & 15 & 16 \\
\hline 中小規模 & 観測された分散比 & 5.09 & 9.63 & 8.67 & 27.02 & 13.83 & 9.12 & 7.80 & 15.80 \\
\hline ゼネコン & $\mathrm{P}$-值 & $0.01 * *$ & $\mathrm{P}<0.01 * *$ & $P<0.01 * *$ & $\mathrm{P}<0.01 * *$ & $\mathrm{P}<0.01 * *$ & $P<0.01 * *$ & $\mathrm{P}<0.01 * *$ & $\mathrm{P}<0.01 * *$ \\
\hline \multicolumn{2}{|r|}{ 項目 } & 17 & 18 & 19 & 20 & 21 & 22 & 23 & \\
\hline 中小規模 & 観測された分散比 & 17.79 & 4.10 & 5.60 & 8.44 & 11.33 & 0.66 & 16.92 & \\
\hline ゼネコン & P-值 & $P<0.01 * *$ & $0.02 * *$ & $0.01 * *$ & $\mathrm{P}<0.01 * *$ & $P<0.01 * *$ & 0.52 & $P<0.01 * *$ & \\
\hline
\end{tabular}


表-4 より, 評価項目 4 (資格)，5（研究委員会・学 会活動），9（安全管理力），21（危機管理）が有意で あることが確認された．よって，これらの評価項目はべ テランにおいて，業種・業態間で技術力の評価值に差が あることがわかる。

次に，業種・業態別に着目し，各評価項目で年代間の 評価值の差異を見るため，同様にして，一元配置の分散 分析を行った. 中小規模ゼネコンの分散分析の結果を表 -5, 大規模ゼネコンの分散分析の結果を表-6, 建設コン サルの分散分析の結果を表-7 に示寸. なお，表-5 から 表-7においても，統計的な有意差のある評価項目の P值の闌に黄色を付している.

表-5 より，評価項目 1 (専門知識)，2（資料やデー 夕の管理・分析・解析力）, 3 （報告書作成・取りまと め力），6（技術的な企画・改善の提案），7，8，9，10

(工程・品質・安全・コス卜管理)，11，12（技術営 業・指導力），13（プロポーザルコンペ対応力），14

(企画・改善意識)，15，16，17（説明・調整・交渉・ プレゼンテーション力），21（危機管理力），23（統 率力）では $5 \%$ 水準で有意であることが確認された。 よ って, これらの評価項目は中小規模ゼネコンにおいて, 年代間で技術力の評価值に差があることがわかる.

表-6より，1 (専門知識），2（資料やデータの管 理・分析・解析力），3（報告書作成・取りまとめ力）, 5 (研究委員会・学会活動) 6 (技術的な企画 - 改善の提 案），7，8，9，10（工程・品質・安全・コス卜管理）, 11，12（技術営業・指導力），13（プロポーザルコンペ 対応力），14 (企画・改善意識)，15，16，17 (説明・ 調整・交渉・プレゼンテーション力），18（責任感）, 20 (倫理観)，21（危機管理力），22（国際性），23 （統率力）では $5 \%$ 水準で有意であることが確認された。 よって, これらの評価項目は大規模ゼネコンにおいて, 年代間で技術力の評価値に差があるとわかる.

表-7 より，1 (専門知識），4 (資格），5（研究委員 会・学会活動）6（技術的な企画・改善の提案），7，8, 9, 10 (工程・品質・安全・コス卜管理），11，12（技 術営業・指導力），13（プロポーザルコンペ対応力）, 14 (企画・改善意識），15，16，17（説明・調整・交 渉・プレゼンテーション力），21（危機管理力）， 23

（統率力）では 5\%水準で有意であることが確認された. よって, これらの評価項目は建設コンサルにおいて, 年 代間で技術力の評価值に差があることがわかる.

\section{（5）業種・業態別の技術力評価の重みに関する考察}

表-2 において，年代別の評価項目 19，20 は評価值に 差がなく, また, 図-5より, これらの平均值が 4 以上と 高いことから, 積極性と倫理観は業種・業態や年代によ らず高く評価されることがわかる．また，専門知識，技
表-6 大規模ゼネコンの一元配置分散分析(年代別)

\begin{tabular}{|c|c|c|c|c|c|c|c|c|c|}
\hline & & & & & & \multicolumn{2}{|c|}{ F境界値: 3.04} & \multicolumn{2}{|c|}{ **:5\%有意 } \\
\hline \multicolumn{2}{|r|}{ 項目 } & 1 & 2 & 3 & 4 & 5 & 6 & 7 & 8 \\
\hline 大規模 & 観測された分散比 & 30.64 & 22.99 & 22.68 & 1.57 & 14.78 & 64.15 & 8.80 & 3.52 \\
\hline ゼネコン & P-值 & $P<0.01$ * * & $P<0.01 * *$ & P P $0.01 * *$ & 0.21 & $P<0.01 * *$ & $P\langle 0.01 * *$ & $P\langle 0.01 * *$ & $0.03 * *$ \\
\hline \multicolumn{2}{|r|}{ 項目 } & 9 & 10 & 11 & 12 & 13 & 14 & 15 & 16 \\
\hline 大規模 & 観測された分散比 & 3.36 & 47.63 & 51.09 & 86.96 & 43.99 & 34.70 & 11.99 & 50.78 \\
\hline ゼネコン & P-值 & $0.04 * *$ & $P<0.01 * *$ & $P<0.01 *$ & $P<0.01 * *$ & $\mathrm{P}<0.01 * *$ & $P<0.01 * *$ & $P<0.01 * *$ & $\mathrm{P}<0.01 * *$ \\
\hline \multicolumn{2}{|r|}{ 項目 } & 17 & 18 & 19 & 20 & 21 & 22 & 23 & \\
\hline 大規模 & 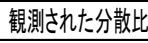 & 24.49 & 4.27 & 2.10 & 10.10 & 31.43 & 4.35 & 54.04 & \\
\hline ゼネコン & P-值 & $P<0.01 * *$ & $0.02 * *$ & 0.13 & $P<0.01 * *$ & $P<0.01 * *$ & $0.01 * *$ & $P<0.01 * *$ & \\
\hline
\end{tabular}

表-7＼cjkstart建設コンサルの一元配置分散分析(年代別)

\begin{tabular}{|c|c|c|c|c|c|c|c|c|c|}
\hline & & & & & & \multicolumn{2}{|c|}{ F境界值: 3.07} & \multicolumn{2}{|c|}{ **: 5\%有意 } \\
\hline \multicolumn{2}{|r|}{ 項目 } & 1 & 2 & 3 & 4 & 5 & 6 & 7 & 8 \\
\hline \multirow{2}{*}{$\begin{array}{c}\text { 建設 } \\
\text { コンサル }\end{array}$} & 観測された分散比F0 & 19.43 & 1.84 & 3.01 & 24.82 & 15.30 & 15.85 & 28.84 & 21.10 \\
\hline & P-值 & $P<0.01 * *$ & 0.16 & 0.05 & $P<0.01 * *$ & $P<0.01 * *$ & $P<0.01 * *$ & $P<0.01 * *$ & $\mathrm{P}<0.01 * *$ \\
\hline \multicolumn{2}{|r|}{ 項目 } & 9 & 10 & 11 & 12 & 13 & 14 & 15 & 16 \\
\hline \multirow{2}{*}{$\begin{array}{c}\text { 建設 } \\
\text { コンササル }\end{array}$} & 観測された分散比F 0 & 4.49 & 27.97 & 36.66 & 77.38 & 38.65 & 7.11 & 5.89 & 29.76 \\
\hline & P-值 & $0.01 * *$ & $P<0.01 * *$ & $P<0.01 * *$ & $P<0.01 * *$ & $P<0.01 * *$ & $P<0.01 * *$ & $P<0.01 * *$ & $\mathrm{P}<0.01 * *$ \\
\hline \multicolumn{2}{|r|}{ 項目 } & 17 & 18 & 19 & 20 & 21 & 22 & 23 & \\
\hline \multirow{2}{*}{$\begin{array}{c}\text { 建設 } \\
\text { コンサル }\end{array}$} & 観測された分散比F0 & 10.99 & 1.10 & 1.26 & 0.52 & 7.89 & 2.04 & 32.11 & \\
\hline & P-值 & $P<0.01 * *$ & 0.34 & 0.29 & 0.60 & $P<0.01 * *$ & 0.13 & $P<0.01 * *$ & \\
\hline
\end{tabular}

表-8 自治体アンケート概要

\begin{tabular}{|c|c|}
\hline アンケート実施日 & 平成23年11月中旬 12月 15 日 \\
\hline 調査対象 & 47都道府県, 19政令指定都市 \\
\hline 調査方法 & $\begin{array}{l}\text { ·建設系部局で土木技術職員の評価·育成に携わっ } \\
\text { ている立場の人にに回答してもうう. } \\
\text {-中部支部委員会で配布, 回答用エクセルシート回収 } \\
(\text { メール) }\end{array}$ \\
\hline $\begin{array}{l}\text { 主な調查項目 } \\
\text { ※一部抜粋 }\end{array}$ & $\begin{array}{l}\text { ·評価について(評価制度·業績評価·評価指標など) } \\
\text { ·育成(OJT実施·資格取得協力の有無） } \\
\text { •キャリアプラン }\end{array}$ \\
\hline 回収状況 & 49団体 $(74 \%)$ \\
\hline
\end{tabular}

術的な企画・改善の提案, 工程・品質・コス卜管理, 技 術指導力, 企画・改善意識, 説明力, 責任感, 統率力は 年代によってのみ差があることがわかる.

表-2 から表-7 よりコスト管理力, 技術指導・提案力, 企画・改善意識, 説明・調整・交渉・統率力の評価值は 業種・業態ではなく, 各年代によって差があり、図-5 から経験を積むごとに評価の重みが増す評価項目である といえる. また, 安全管理は業種・業態だけでなく, 年 代も評価值の差に影響を与えているといえる．また，表 -2 から表-4, 表-5 から表-7 を比べると, 業種・業態別よ り，年代別で評価值に差がある評価項目が多いことがわ かる.

図-5 のベテランにおいて，大体の項目がどの規模も 評価值が似通っていることがわかるが，その中で評価項 目 4, 5 は評価值の平均にばらつきがある. また，表-4 より，これらの評価項目は評価值に差があることがわか る. よって, 4 資格, 5 研究委員会活動・学会活動のべ テランに対する評価は業種・業態によって差があり, 中 小規模ゼネコン, 大規模ゼネコン, 建設コンサルの順に 評価の重みが増すことがわかる.

図-5 の大規模ゼネコンにおいて 8品質管理の平均值が 年代順に上がるのではなく、中堅が高いことがわかる. 
表-6より 8 品質管理は評価值に差があり，品質管理の技 術力は，ベテランより中堅に求められていることがわか る. 建設コンサルに着目すると, 評価項目 4, 15 の平均 值が年代順に上がっていないことがわかる．表-7 より， 評価項目 4，15 は評価值に差があり，資格，説明力など は, ベテランより中堅に求められていることがわかる. また，建設コンサルで評価項目 12 に着目すると, 最も 年代によって評価值に差があることがわかる．表-7よ り，評価項目 12 は統計的にも評価值に差がみられ，技 術指導力は若手，中堅，ベテランで評価值に大きく差が あることがわかる。

\section{3. 民間企業・自治体における育成・キャリアプ ランに関する現状分析}

本章では，民間企業・自治体向けに実施したアンケー 卜調査結果にもとづき，技術者育成・キャリアプランに 関する現状分析を行った.

\section{（1）育成に関する企業・自治体アンケート結果}

自治体アンケートの概要を表-8 に示す。また，民間 企業と自治体共通で実施した，技術者育成・キャリアプ ランの現状に関する質問の内容を表-9 に示す.これら を用いて，民間企業と自治体の特徵や違いを分析する. なお，本研究では，キャリアプランとは自らの職場生活 における将来の目標やゴールを決め，それを実現させる ために計画をたてることを指し，キャリアパスとは，ど んな仕事をどれくらいの期間担当し，どの程度の習熟レ ベルに達すれば，どういうポストに就けるのかといった キャリアアップの道筋や基準・条件を明確化したもの，

として回答者に情報提供している.

まず，OJTに関する質問 1 の集計結果を図-6に示す. これより，大規模ゼネコンでは 28\%，建設コンサルでは 25\%の企業が OJT を制度として確立しているのに対し， 中小規模ゼネコンでは，その半数末満の 11\%であり、 OJT が定着していないことがうかがえる。次に，中小規 模ゼネコンでは 53\%，大規模ゼネコンでは 60\%，建設コ ンサルでは 65\%の企業が OJT を制度として確立してい るか，ある程度実施しており，OJT に関心があることが わかる. 自治体では 44\%の団体が OJT に関心があり， 民間企業に比べて割合が低いことがわかる，また自治体 のうち 46\%の団体が，OJTを組織の担当者に任せており， 業種・業態の中で一番全社的な取り組みが低いと言える。

図-6の「その他」に対する自由回答を表-10 に示す. なお，企業・団体が特定される回答には企業・団体名を ×に置き換えている．これより，民間企業では現場研修， 自治体では職場研修が実施されていることがわかる。 中
表-9 技術者育成・キャリアプランに関する質問内容 (企業・自治体向け)

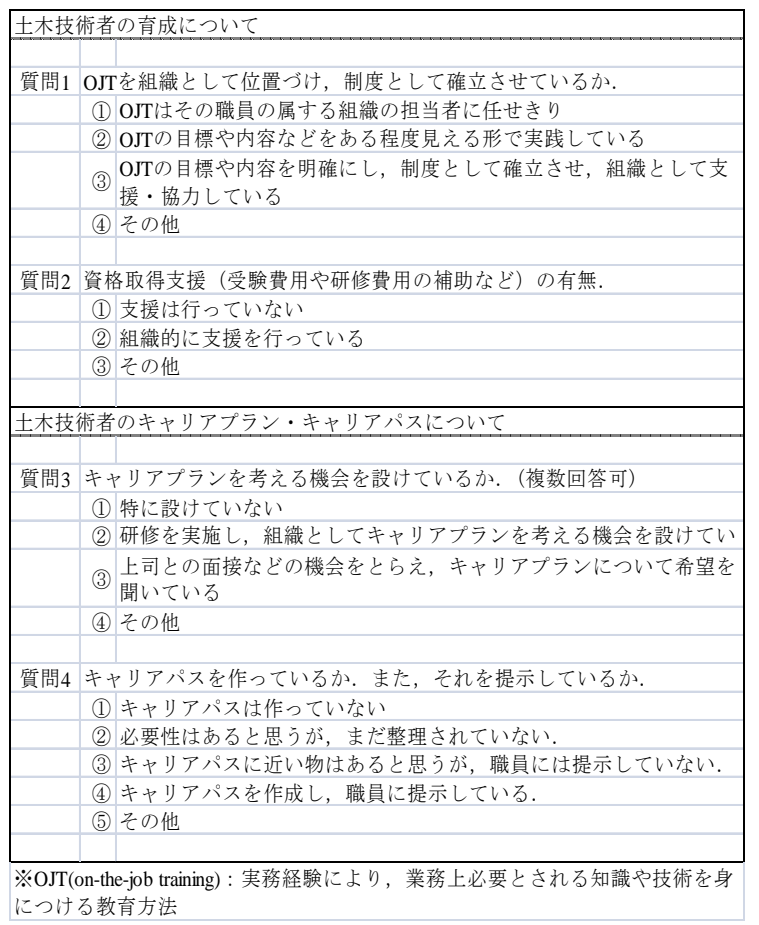

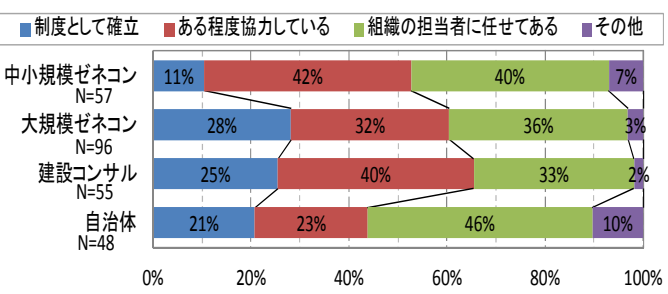

図-6 OJTによる育成制度・支援協力の有無

表-10「OJTによる育成制度・支援協力の有無」の 自由回答

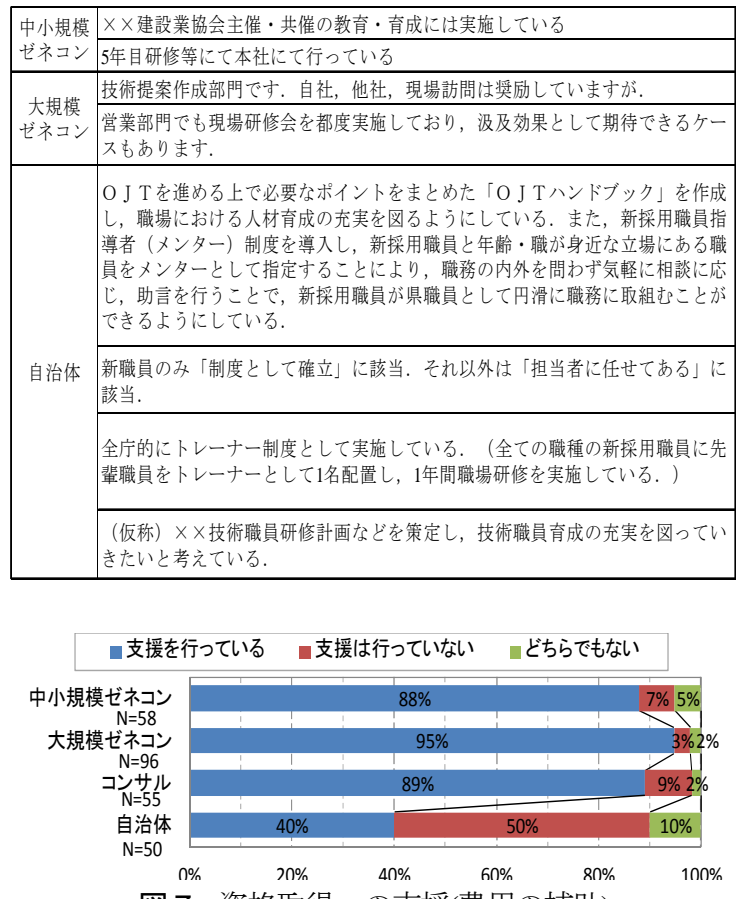

図-7 資格取得への支援(費用の補助) 
小ゼネコンでは建設業協会(他団体)に依存しており， OJT 支援を研修や育成制度設計に組み込む必要があると 思われる.また自治体では, 新採用職員に対し先輩職員 を指導者として配置する制度もあることがわかる。

次に，資格取得支援に関寸る質問 2 の集計結果を図-7 に示寸。これより，中小規模ゼネコンでは 88\%，大規模 ゼネコンでは 95\%，建設コンサルでは 89\%の企業で資格 取得の支援を行っており，自治体では，40\%の団体で資 格取得の支援を行っていることがわかる。この背景とし て, 自治体からの発注条件から民間が資格を必要として いることが伺える。

図-7の「どちらでもない」に対する自由回答を表-11 に示寸，なお，団体が特定される回答には団体名を×に 置き換えている. 中小規模ゼネコンと建設コンサルでは, 資格取得後に資格手当が支給されていること，大規模ゼ ネコンや自治体では，業務に関係のある特定の資格のみ 支援されていることがわかる，また，自治体では，資格 の情報提供をしていることもわかる.

\section{(2) キャリアプラン・キャリアパスに関する企業・自 治体アンケート結果}

キャリアプランに関する質問 3 の集計結果を図-8に示 す．これより，大規模ゼネコンでは 16\%，建設コンサル では $13 \%$ ，自治体では $16 \%$ 研修を実施し，かつ上司と 面接する機会を設けているが，中小規模ゼネコンで両方 実施されているのは，2\%と少ないことがわかる．また， 大規模ゼネコンでは 36\%の企業，中小規模ゼネコンでは その約 2倍の 73\%の企業でキャリアプランを考える機会 を設けていないことがわかる。

図-8の「その他」に対する自由回答を表-12 に示す. これより，コンサルはキャリアプランを考える機会を制 度として運用していることがわかる．また自治体では人 事異動自己報告書を提出寸る際に上司と面談を行い，中 堅職員対象の研修が制度化されていることがわかる.

キャリアパスに関する質問 4 の集計結果を図-9 に示す. これより，大規模ゼネコンでは 30\%，建設コンサルで は26\%の企業がキャリアパスを作成し社員に提示してい るか, キャリアパスに近いものがあり, キャリアパスの 必要性を感じていることがわかる，中小規模ゼネコンで は 7\%の企業, 自治体では $12 \%$ 団体がキャリアパスの 必要性を感じており, 特に自治体では大規模ゼネコン, 建設コンサルの半数以下の割合であり, キャリアパスに 対する意識が低いことがわかる．また，中小規模ゼネコ ンでは，60\%の企業でキャリアパスを作っていないこと， また自治体では，70\%の団体でキャリアパスを作ってい ないことがわかる.この背景として, 中小規模ゼネコン では, 表-14に後述するように即戦力となる転職技術者 を雇用していることが挙げられる．自治体では昇任に経
表-11「資格取得への支援」の自由回答

\begin{tabular}{|c|c|}
\hline $\begin{array}{l}\text { 中小規模 } \\
\text { ゼネコン }\end{array}$ & 資格取得の費用補助はないが，資格取得者には資格手当を支給している。 \\
\hline \multirow{2}{*}{\begin{tabular}{c|c} 
大規模 \\
ゼネ゙ン
\end{tabular}} & $\begin{array}{l}\text { 業茅に必要な資格取得の重要性は認識が行き届くよう，啓もうされている環境 } \\
\text { があります。 }\end{array}$ \\
\hline & 特定の資格のみ支援 \\
\hline \begin{tabular}{c|} 
建設 \\
コンサル
\end{tabular} & $\begin{array}{l}\text { 金銭面を捉えるのであれば, 取得の過程における支援はないが取得後の手当と } \\
\text { して支給しているものがある. }\end{array}$ \\
\hline \multirow{6}{*}{ 自治体 } & 他に, 技術アドバイザー制度 \\
\hline & 資格の関連情報を庁内ポータルサイトに掲載し，情報提供を行っている。 \\
\hline & 今後, 技術士，一級建築士，建築主事等の資格取得への啓蒙活動を行う予定. \\
\hline & $\begin{array}{l}\text { 土木技術職員に限らず，専門能力向上を目的とした研修費用の助成制度があ } \\
\text { ク，その制度の要件を満たせば資格取得も可能である. } \\
\end{array}$ \\
\hline & $\begin{array}{l}X \times \text { 建設技術協会が実施している「資格取得奨励制度」を活用．国家資格及び } \\
\text { 建設分野に関倸のある资格の取得に倸る費用に対し，3,000円〜 } 5,000 \text { 円 } / 1 \text { 件 } \\
\text { を補助. }\end{array}$ \\
\hline & 平成17年度から平成22年度まで資格取得の支援（受験費用）を実施していた。 \\
\hline
\end{tabular}

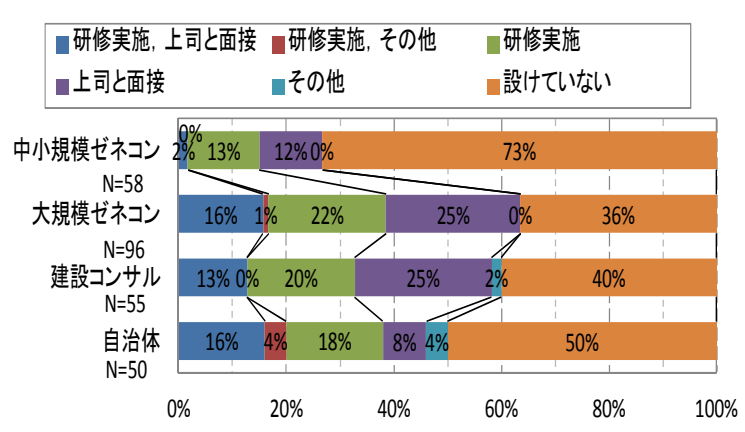

図-8＼cjkstart社員がキャリアプランを考える機会

表-12「社員がキャリアプランを考える機会」の 自由回答

\begin{tabular}{|c|c|}
\hline $\begin{array}{l}\text { 大規模 } \\
\text { ゼネンン }\end{array}$ & 講習会などの紹介 \\
\hline \begin{tabular}{c|} 
建設 \\
コンサル
\end{tabular} & 制度として運用中 \\
\hline \multirow{2}{*}{ 自治体 } & $\begin{array}{l}\text { 人事異動自己申告書にキャリアプランを記入する欄を設けており、提出にあた } \\
\text { り上司と面談を行うこととしている. }\end{array}$ \\
\hline & 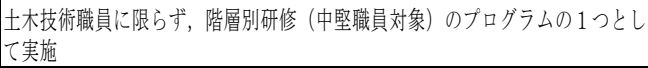 \\
\hline
\end{tabular}

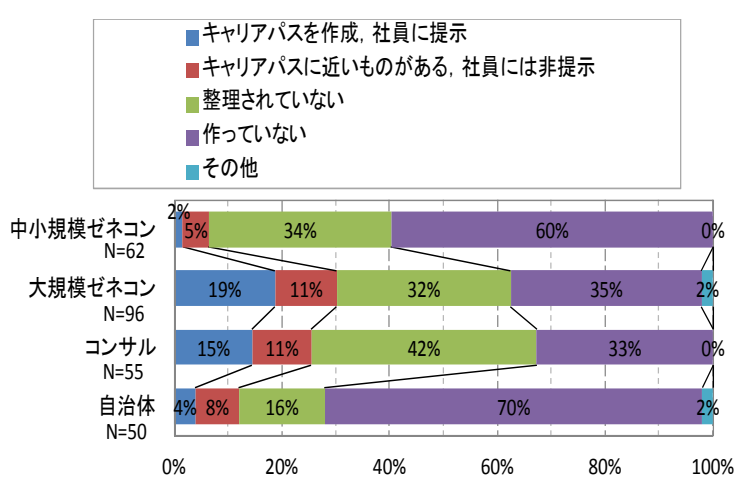

図-9 キャリアパスの有無とその提示

表-13「キャリアパスの有無とその提示」の 自由回答

\begin{tabular}{|l|l|}
\hline $\begin{array}{l}\text { 大規模 } \\
\text { ギネンリリアパスに近いものがあり，社員に提示している。 }\end{array}$ \\
\hline 自治体 & $\begin{array}{l}\text { キャリアパスは策定しているが，技術職の習熟しベルなど，詳細については提 } \\
\text { 示していない. }\end{array}$ \\
\hline
\end{tabular}


表-14 企業アンケート自由回答(評価，育成・キャリアプラン)

※太字 $\rightarrow$ カゴリー内で複数回答があったもの

\begin{tabular}{|c|c|c|c|}
\hline & \multicolumn{2}{|r|}{ 建設会社 } & \multirow{2}{*}{ 建設コンサル } \\
\hline & 中小規模ゼネコン & 大規模ゼネコン & \\
\hline \multirow{9}{*}{$\begin{array}{l}1 \\
\text { 評 } \\
\text { 価 }\end{array}$} & $\begin{array}{l}\text { 担当する工事における特性(工事の大き } \\
\text { さ, 利益率等) が異なるため評価は難 } \\
\text { しい.（2件） }\end{array}$ & 万人に公平な評価, 継続は難しい（6件） & 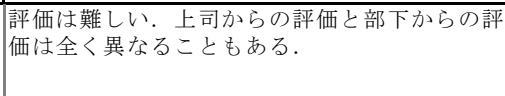 \\
\hline & $\begin{array}{l}\text { 評価については若年層は資格取得から始 } \\
\text { まり，中堅層は部下の教育としている. }\end{array}$ & $\begin{array}{l}\text { 評価のマニュアルのみで全てを評価してよいものか } \\
\text { は疑問である. }\end{array}$ & $\begin{array}{l}\text { 評価・分析の重要性は認識しているが, 外部環 } \\
\text { 境変化のスピードについていない. }\end{array}$ \\
\hline & $\begin{array}{l}\text { 中小建設業では評価指標，OJT,キャリア } \\
\text { パスを実施しているのは皆無であると思 } \\
\text { う. }\end{array}$ & $\begin{array}{l}\text { 利益, 品啠成績など目に見える数字だけでなく業務 } \\
\text { の取り組み, 努力の程度など日頃の行動に対し } \\
\text { て評価できるとよい. }\end{array}$ & $\begin{array}{l}\text { 評価結果について評価者と意見交換を行うこと } \\
\text { が㕕成に効果的である.艮いところを伸ばし, } \\
\text { 足りないところを改善する指導を充実させてい } \\
\text { きたい. }\end{array}$ \\
\hline & & $\begin{array}{l}\text { 公平な評価は難しい. 不公平評価の排除と後年に引 } \\
\text { きづらない”許年度評価”であることを本人に説明し } \\
\text { ている. }\end{array}$ & \\
\hline & & $\begin{array}{l}\text { 評価のばらつきを補うため評価者を } 2 \text { 人にしてい } \\
\text { る.支店と営業所での評価格差を是正するため, 評 } \\
\text { 価者の教育を行っている. }\end{array}$ & \\
\hline & $\begin{array}{l}\text { 発注者の施工成績評価はマニュアル化さ } \\
\text { れており, 専門的分野において施工に携 } \\
\text { わる業者には (マニュアルが専門性を捕 } \\
\text { 捉しきっていないため) 不向きと思われ } \\
\text { る. }\end{array}$ & $\begin{array}{l}\text { 発注者が行う施工成績評価は工種や検査官による差 } \\
\text { 異を゙ことがある. }\end{array}$ & \multirow[t]{2}{*}{ 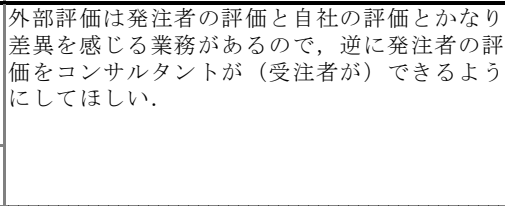 } \\
\hline & $\begin{array}{l}\text { 入札段階の評価で”実績”と”地域性”のウ } \\
\text { エイトが高く，偏りすぎている. }\end{array}$ & 発注者が行う業務評価の評価基準の公開を望む. & \\
\hline & $\begin{array}{l}\text { 施工成績評価は. 総合評価落札方式が普 } \\
\text { 及寸るで企業点にかかわる部分であ } \\
\text { るので, 自治体間での温度差（偏り）が } \\
\text { あってはならない. }\end{array}$ & & $\begin{array}{l}\text { 「業務評定点」発注者の期待に応える品質成果 } \\
\text { がその生産過程も含めて適切に評価されてい } \\
\text { る. }\end{array}$ \\
\hline & $\begin{array}{l}\text { 発注者の姿勢が評価に現れる.例えば, } \\
\text { 無難であること, 他に指摘されないこ } \\
\text { と, 施工者との共同意識が希薄なこと. } \\
\end{array}$ & & \\
\hline \multirow{6}{*}{$\begin{array}{l}2 \\
\text { 育 } \\
\text { 成 } \\
\text {. }\end{array}$} & $\begin{array}{l}\text { 人材の育成の時間が持てない, 落札率 } \\
\text { の低下, 一般競争入札により利益が出 } \\
\text { ないので, 現場管理に対する評価を優 } \\
\text { 先している. (5件) }\end{array}$ & $\begin{array}{l}\text { 一般的なものについては容易であるが，性格的な個 } \\
\text { 人差を伴うものは難しい. }\end{array}$ & $\begin{array}{l}\text { 中小コンサルタントでは, 人材が定着せず育成 } \\
\text { がままならない }\end{array}$ \\
\hline & $\begin{array}{l}\text { 落札率低下で育成する余裕がないので即戦 } \\
\text { カをを雇用しているのが現状である. (2件) }\end{array}$ & $\begin{array}{l}\text { 年代にあった現場編成が上手くできず，過去のよう } \\
\text { に自然に技術力を射にける環境がなくなってきて } \\
\text { いる. }\end{array}$ & $\begin{array}{l}\text { 外注依存が高く, 若いうちに身につけるべき基 } \\
\text { 礎的技術の育成に工艺いる }\end{array}$ \\
\hline & $\begin{array}{l}\text { 年間労働日数が多く長時間労働, 頑張つ } \\
\text { ても社会的評価が低いため右手技術者が } \\
\text { 離職するので, 技術伝承は難しい. }\end{array}$ & $\begin{array}{l}\text { 総合評価落札方式により現場配置予定技術者の技術 } \\
\text { 点が影響するので評価の高い技術者が同じ工種の現 } \\
\text { 場に偏るなど, 本人の希望に合った多様な現場配置 } \\
\text { ができなくなっている. }\end{array}$ & $\begin{array}{l}\text { 社員育成が現場の上司任せになり，その当たり } \\
\text { 外れで, 結果, 土木鎅から去っていく者が少 } \\
\text { なくない. }\end{array}$ \\
\hline & & $\begin{array}{l}\text { ある程度, OJTや資格取得によってできる仕組みに } \\
\text { なっていると感じられる. }\end{array}$ & $\begin{array}{l}\text { コンサルタント社員の育成は, 業種の性格上不 } \\
\text { 可久で直接的に経営に跳返る。 }\end{array}$ \\
\hline & $\begin{array}{l}\text { キャリアプラン・パスは会社組織には必 } \\
\text { 要と考えるが, 各個人の意欲も関係する } \\
\text { ので難しい. }\end{array}$ & $\begin{array}{l}\text { 人材育成は最重要課題ととらえ，基本計画をもとに } \\
\text { 取り組んでいる. }\end{array}$ & $\begin{array}{l}\text { 評価結果について評価者とコミュニケーション } \\
\text { を行うことが社員の有成に効果的である. }\end{array}$ \\
\hline & & $\begin{array}{l}\text { 公共工事の減少やダンピング受注が人材育成に影響 } \\
\text { していなか危惧している. }\end{array}$ & $\begin{array}{l}\text { コンサルタントの社会的な地位向上と魅力ある } \\
\text { 職場環境の整備が育成につながる. }\end{array}$ \\
\hline
\end{tabular}

験年数を反映した人事が大きく支配していると推察され るが，この点については今後さらなる検討が必要である. 図-9の「その他」に対する自由回答を表-13 に示す. 大規模ゼネコンでも自治体でもキャリアパスはあり，図 -9 からもわかるように，大規模ゼネコンでは社員に提 示しているが，自治体では技術レベルと必要性を詳細に 把握していないことがわかる.

\section{4. アンケート自由回答による技術者を取り巻く 現状と課題に関する整理}

企業アンケートの自由回答からキーワードを抽出，分 類し，設問で読み取ることのできない技術者を取り巻く 現状, 課題について整理した.
中小規模ゼネコン・大規模ゼネコン・建設コンサルの 3 つの業種・業態に分類し, 企業アンケートの自由回答 の中からキーワードを含むセンテンスを抽出，分類した 結果を表-14，表-15，表-16に示寸。ここでは，「1評価， 2 育成・キャリアプラン，3 上木業界の現状，4重要・必 要事項, 5土木業界の課題, 6希望, 7不安」の 7つのカ テゴリーに分類した. なお, 評価については社内的な内 部評価と社外との関係による外部評価の $2 つ に$ 細分化し た. また，本表では，カテゴリー内で複数回答があって まとめたものを太字で示し，括弧書きで件数を表記する.

\section{(1) 土木技術者の評価・育成について}

表-14 より，1 評価について, 内部評価のカテゴリー では，いずれの業種・業態でも評価の困難さが示されて おり, 中小規模ゼネコンでは担当する工事特性が異なる 
表-15 企業アンケート自由回答(現状，重要・必要事項)

※太字 $\rightarrow$ カゴリー内で複数回答があったもの

\begin{tabular}{|c|c|c|c|}
\hline & \multicolumn{2}{|r|}{ 建設会社 } & \multirow{2}{*}{ 建設コンサル } \\
\hline & 中小規模ゼネコン & 大規模ゼネコン & \\
\hline \multirow{11}{*}{$\begin{array}{l}3 \\
\text { 土 } \\
\text { 木 } \\
\text { 業 } \\
\text { 界 } \\
\text { の } \\
\text { 現 } \\
\text { 状 }\end{array}$} & \multicolumn{3}{|c|}{ 3. 1 受注量の激減と受注価格の低下により発生している問題 } \\
\hline & $\begin{array}{l}\text { 一般競争入札により，低落札に誘導さ } \\
\text { れ，利益が出ないばかりか受注の予定さ } \\
\text { え目途が立たない }\end{array}$ & $\begin{array}{l}\text { 業界会体の収縮化の中で, いかに重要性とやりがい } \\
\text { 感じて集中できる環境を作り出すのか（難しくなっ } \\
\text { ている） }\end{array}$ & $\begin{array}{l}\text { 古くより資格制度, 社員評価制度, ISO対応をし } \\
\text { ているが近年の受注量の減少により，縮小傾向 } \\
\text { にある. }\end{array}$ \\
\hline & 即戦力となる人材を雇用(2件) & & 人材が定着しないので, 育成がままならない. \\
\hline & $\begin{array}{l}\text { これまで人材育成を考える余裕がなかっ } \\
\text { たが，アンケートに答えることによって } \\
\text { 重要性が分かった. }\end{array}$ & $\begin{array}{l}\text { 日常業務に追われ，キャリアパスを考える余裕がな } \\
\text { い中, アンケートの結果に興味を持つ. }\end{array}$ & $\begin{array}{l}\text { アンケートにあるような評価制度について考え } \\
\text { るより，業界はもつと大変. }\end{array}$ \\
\hline & $\begin{array}{l}\text { 自社で研修する余裕がなく, 社外での講 } \\
\text { 習, 研修が主となる }\end{array}$ & $\begin{array}{l}\text { 土木系技術系社員の技術レベルがかなり下がってき } \\
\text { ており, 指示待ち人間になってきている中で, 社員 } \\
\text { 教育を基礎からやっている. }\end{array}$ & $\begin{array}{l}\text { 外注依存が高く, 若いうちに身につけるべき基 } \\
\text { 礎的技術の育成時間が減っており，報告書作成 } \\
\text { の修正指導時間も減っている. }\end{array}$ \\
\hline & $\begin{array}{l}3 \text { 3. } 2 \text { 評価・育成は現実には難しい } \\
\text { という見解 }\end{array}$ & $\begin{array}{l}3 \text { 見解 } \\
3\end{array}$ 評価・育成の問題を補っているという & \begin{tabular}{|ll}
3.4 & 評価・育成は他業種より進んでいる \\
が，問題はあるという見解
\end{tabular} \\
\hline & $\begin{array}{l}\text { 工事現場で民間とのトラブルに振り回さ } \\
\text { れ，技術の育成にさける時間がない. }\end{array}$ & \multirow{2}{*}{$\begin{array}{l}\text { 公平な評価は難しい. 不公平評価の排除と後年に引 } \\
\text { きづらない”単年度評価”であることを本人に説明し } \\
\text { ている. }\end{array}$} & $\begin{array}{l}\text { 以前から資格制度，社員評価制度ISO対応してい } \\
\text { るが， 業務量の激減により縮小傾向にある。 }\end{array}$ \\
\hline & $\begin{array}{l}\text { 現場管理に対する評価が優先され「育 } \\
\text { 成」を見据えた教育・評価が難しくなっ } \\
\text { ている. }\end{array}$ & & $\begin{array}{l}\text { 評価者による差異を解消寸るため, 被評価者本 } \\
\text { 人による評価と突き合わせ，評価者が説明して } \\
\text { いる. }\end{array}$ \\
\hline & $\begin{array}{l}\text { 人材としての評価・養成まで我々小企 } \\
\text { 業としては考える余裕がない(5件) }\end{array}$ & $\begin{array}{l}\text { 評価のばらつきを補うため評価者を } 2 \text { 人にしてい } \\
\text { る. 支店と営業所での評価格差を是正するため, 評 } \\
\text { 価者の教育を行っている. }\end{array}$ & \multirow[t]{3}{*}{$\begin{array}{l}\text { 目標設定による評価制度は，建設コンサルでは } \\
\text { 目標の立て方が難しいので運用が困難であるた } \\
\text { め，ほかに重きを置いている。. }\end{array}$} \\
\hline & $\begin{array}{l}\text { 技術者として技術力を高めることができ } \\
\text { たとしも, 企業としてそれを評価して } \\
\text { 給料に反映させることが出来ない }\end{array}$ & \multirow[t]{2}{*}{$\begin{array}{l}\text { 大学で土木工学として必須のコンクリート工学, 地 } \\
\text { 盤工学, 構造力学を履修しないで入社する社員もい } \\
\text { る. (再教育を行っている) }\end{array}$} & \\
\hline & 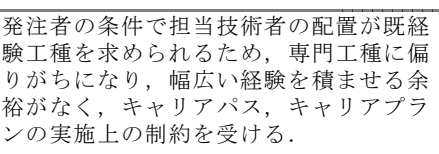 & & \\
\hline \multirow{5}{*}{$\begin{array}{c}4 \\
\text { 重 } \\
\text { 要 } \\
\text { • } \\
\text { 必 } \\
\text { 要 } \\
\text { 事 } \\
\text { 項 }\end{array}$} & \multicolumn{2}{|l|}{ 社会的地位の向上が重要である. (2件) } & $\begin{array}{l}\text { 社会全体で土木技術者を評価, 育成, 位置づけ } \\
\text { ことが求められている }\end{array}$ \\
\hline & $\begin{array}{l}\text { 社会に出てからも勉強し, 専門知識を高 } \\
\text { めることが当たり前と土木系技術者が考 } \\
\text { えるようになること. そうなれば社会的 } \\
\text { 地位や技術力アップにつながる }\end{array}$ & $\begin{array}{l}\text { プレゼンテーションカの向上が必要不可欠で, 社員 } \\
\text { の能力とやる気が会社の財産である. }\end{array}$ & $\begin{array}{l}\text { 人事・教育部門による上司の教育や, 評価者と } \\
\text { なる上司以外による育成や指導支援がもつと必 } \\
\text { 要である. }\end{array}$ \\
\hline & \multicolumn{3}{|c|}{ 会社や技術者にとって評価, 教育, 育成は重要である。(4件) } \\
\hline & $\begin{array}{l}\text { 多工種を総合的に管理する工事と専門的 } \\
\text { 工種だけを管理する工事と評価が違うは } \\
\text { ずであり, この反映が必要 }\end{array}$ & $\begin{array}{l}\text { 業務に重要性とやりがいを感じて集中できる環境を } \\
\text { つることが社員のレベルアップにつながる }\end{array}$ & \\
\hline & $\begin{array}{l}\text { 将来展望のある会社にしたいが, そのた } \\
\text { めには健全な経営が必要である. }\end{array}$ & \multicolumn{2}{|c|}{ 社員の評価・育成について正確で課題に対応した社内指標が必要(2件) } \\
\hline
\end{tabular}

こと，大規模ゼネコンでは公平な評価の難しさ，評価の 継続性，評価マニュアルのみでの評価に疑問を感じてい ること，個人的な感情が入ってしまうことが挙げられて いる.

建設会社では，規模によらず工事の利益によって評価 に影響がある様子が伺える，また，中小規模ゼネコンで は，若年層は資格取得から評価し，中堅では部下の教育 を評価していること，大規模ゼネコンでは，不公平な評 価の排除や，評価の説明，複数の評価者を決定し評価者 への教育実施をしているという実態や，業務への取り組 み方や日頃の行動に対して評価したいとの思いも見られ た. 建設コンサルでは，上（上司）からの評価と下（部 下）からの評価が異なる問題を指摘し，業界の変化のス ピードに評価制度が対応できていないことや，評価結果 について評価者と意見交換を行うことが育成に効果的で

\section{ある示されている.}

また，外部評価のカテゴリーでは，中小規模ゼネコン において, 発注者の施工成績評価の適用性, 受注段階で の実績, 地域性評価の高さの問題, 発注者の施工者との 協働意識の希薄さが指摘されていた. 大規模ゼネコンと 建設コンサルでは，発注者の行う施工成績評価で差異を 感じるという回答がある. 大規模ゼネコンでは，工種や 検査官による差異を感じており, 建設コンサルでは, 自 社の評価と外部評価の差異を感じていることがわかる.

しかし，建設コンサルにおいて，外部評価は業務に適切 な評価指標とも指摘されており，この差異を克服するこ とが課題といえる.

2 育成・キャリアプランのカテゴリーでは，いずれの 業種・業態でもなかなか育成ができないという回答があ る. この背景として，表-14 に示すように中小規模ゼネ 
表-16 企業アンケート自由回答(課題，希望，不安)

※太字 $\rightarrow$ カゴリー内で複数回答があったもの

\begin{tabular}{|c|c|c|c|}
\hline & \multicolumn{2}{|r|}{ 建設会社 } & \multirow{2}{*}{ 建設コンサル } \\
\hline & 中小規模ゼネコン & 大規模ゼネコン & \\
\hline \multirow{3}{*}{$\begin{array}{l}5 \\
\text { お } \\
\text { け } \\
\text { る } \\
\text { る業 } \\
\text { 課界 } \\
\text { 題に } \\
\end{array}$} & \multicolumn{3}{|c|}{ 社員を成長させ，引き上げるための社内教育の方法が見えていない（3件） } \\
\hline & $\begin{array}{l}\text { 各自の成長・成果のばらつきをどう克服 } \\
\text { するが課題. }\end{array}$ & $\begin{array}{l}\text { 即断, 即決の判断力が不足しており, この克服が課 } \\
\text { 道. }\end{array}$ & $\begin{array}{l}\text { コンサルタントという職種の社会的地位向上が } \\
\text { 課題である. }\end{array}$ \\
\hline & $\begin{array}{l}\text { 評価は必要と考えるが, 社内の育成・評 } \\
\text { 価の体制が未到達である. }\end{array}$ & $\begin{array}{l}\text { 重要性とやりがいを感じて集中できる職場環境を作 } \\
\text { 出せるが課題. }\end{array}$ & $\begin{array}{l}\text { 魅力ある職場環境の整備が課題で,これがあっる } \\
\text { てはじめて人材の定者, 育成がきる. }\end{array}$ \\
\hline \multirow{5}{*}{$\begin{array}{l}6 \\
\text { 希 } \\
\text { 望 }\end{array}$} & $\begin{array}{l}\text { アンクートに示された評価項目, 内容は } \\
\text { 非常に参考になった.今後, 階層別の評 } \\
\text { 価をより鮮明にしたい. 評価結果を本人 } \\
\text { の意識改革へつなげたい }\end{array}$ & $\begin{array}{l}\text { 設計変更の提案や現場の技術的問題の解決に技術を } \\
\text { 有効に使って, 発注者とともによ物を造れる } \\
\text { 社員を望む. }\end{array}$ & $\begin{array}{l}\text { 評価結果をもとにいいところを伸ばし,足りな } \\
\text { いところを改善する指導を充実していきたい. }\end{array}$ \\
\hline & $\begin{array}{l}\text { 资世代技術者育成のためにも予定価格に } \\
\text { 近いとここで洛札したい.（亩成に投資 } \\
\text { する資金を碓したい）（保した） }\end{array}$ & $\begin{array}{l}\text { 責任感・積極性を引き出せる体制作り,やりがいを } \\
\text { つて業務を進めていけるような評価・㕕成制度を } \\
\text { 作りたい. }\end{array}$ & \multirow[t]{2}{*}{ 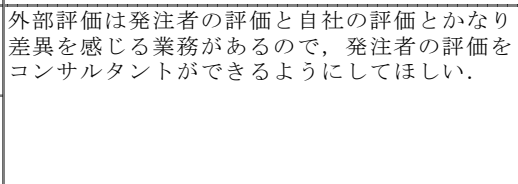 } \\
\hline & \multirow[t]{3}{*}{$\begin{array}{l}\text { (幅広い知識で) 機転の利く社員が必要 } \\
\text { であるので, 各協会, 各学会, 各団体等 } \\
\text { の研修などでヒンを出してほしい. }\end{array}$} & $\begin{array}{l}\text { 誰が評価しても同じ結果が得られ，本当に有効な育 } \\
\text { 成・評価を知りたい. }\end{array}$ & \\
\hline & & $\begin{array}{l}\text { 組織の求める人材, 継続的自己棨発する人材へ向け } \\
\text { て社内度の改革を進めていき. }\end{array}$ & \\
\hline & & 土木技術者の社会的地位向上を望む. & \\
\hline $\begin{array}{l}7 \\
\text { 不 } \\
\text { 安 }\end{array}$ & 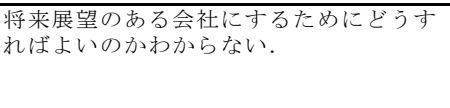 & $\begin{array}{l}\text { 公共工事の減少やダンピング等による受注で人材育 } \\
\text { 成に影響していないか危惧している. }\end{array}$ & $\begin{array}{l}\text { 原発事故によって国民の信頼を失った側面があ } \\
\text {, 信頼を失った技術者の言葉で合意を得られ } \\
\text { るのかと安がある. }\end{array}$ \\
\hline
\end{tabular}

コンでは，人材育成の時間がなく即戦力となる人材を雇 用していることや，利益の低下などがあり，大規模ゼネ コンでは，年代にあった現場編成ができなくなったこと， 建設コンサルでは人材が定着しないことが挙げられる. また，業種・業態によらず個人の意欲，希望とのミスマ ッチが影響し，育成は難しいという回答がある．中小規 模の建設コンサルで社員育成が現場の上司任せになって いることなどによって人材が定着しないという現実と， 中小規模ゼネコンで社会的評価が低いため若手技術者が 離職し，育成できないとの回答もあることから，中小規 模の業界では若手技術者の早期離職が喫緊の課題である ことが確認できた. 社員育成のために, 大規模ゼネコン では，現場経験から技術の継承がなされることや社員の 特性を伸ばすこと，建設コンサルでは，基礎的技術の育 成の工夫や社会的地位の向上，魅力女る職場環境の整備， 評価者とのコミュニケーションが大切であるという回答 が見られた。

\section{（2）土木業界の現状と課題について}

表-15 より，3 土木業界の現状のカテゴリーでは，ど の業種・業態でも受注量が激减していると回答がある. そして，受注量が激减することにより，資格制度や社員 評価制度，ISO 対応が縮小され，利益も上げられなくな るため，人材育成への投資を削減していることが伺える。 特に中小規模のゼネコンでは削減の傾向が顕著に現れて いる。また, 実際, 評価・育成は難しいとの回答がどの 業種・業態でもある. 特に, 中小規模ゼネコンでは，人 材としての評価・育成を考えることに余裕がないことか ら即戦力となる人材を雇用しており，現場管理に対寸る
評価が優先されている.さらに大規模ゼネコンでも, 日 常業務に追われており，土木技術者の技術レベルが下が っていることや，社員が土木に関心を持たなくなってき ていることが問題となっていることがわかる.

一方, 4 重要・必要事項のカテゴリーでは, 社会的地 位の向上が挙げられる. 社会的地位の向上のため, 技術 者にとって必要な事項として, 中小規模ゼネコンでは, 土木技術者が専門知識を社会に出てから高めることが当 たり前と考えること，大規模ゼネコンでは，プレゼンテ ーション力を向上させることが挙げられる. 一方, 企業 にとって必要な事項として, 中小規模ゼネコンでは将来 のビジョンある会社のための健全な経営, 大規模ゼネコ ンでは, 社員の評価・育成の正確な社内指標や, 個の業 務に重要性とやりがいを感じて集中できる環境, 建設コ ンサルでは上司以外の育成支援，社会全体で技術者を評 価・育成し，位置づけることが挙げられる．また，会社 や技術者にとって評価・育成は重要だという回答が大規 模ゼネコン，建設コンサルで4件あった.

表-16 より，5 土木業界の課題のカテゴリーでは，ど の業種・業態でも社内教育の方法と回答がある. 建設会 社では, 規模によらず各技術者の成長・成果のばらつき を解消することで社内教育ができ，また，建設コンサル では新入社員の減少を解消することにより，社内教育が できると回答がある．また，中小規模ゼネコンでは，社 内の育成・評価の体制が未到達であることが課題とされ ている. 大規模ゼネコンや建設コンサルでは，職場環境 が課題になっており, 業務に重要性とやりがいを感じる 環境や, 魅力ある職場環境への整備が重要とされる。一 方, 6 希望のカテゴリーでは, 中小規模ゼネコンと建 
設コンサルで評価結果を用いて本人の意識改革や育成に 用いたいという回答があり，大規模ゼネコンでは，発注 者とともに良いものを造れる職員や継続的自己啓発意識 を支える社内制度の改革がしたいとある. また， 7 不安 のカテゴリーでは, 中小規模ゼネコンでは将来のビジョ ンある会社にする経営方法, 大規模ゼネコンでは, 公共 工事の減少やダンピングの受注による人材育成への影響 が䀣念されている.

\section{5. おわりに}

\section{(1) 得られた知見}

本研究で得られた知見を以下に示す.

・ 2 章の分析より, 大規模ゼネコン・建設コンサルでは, 半数以上が評価項目を決めて評価を行っている一方, 中小規模ゼネコンでは評価項目を決めて評価を行って いる割合が低く, 社内規定が確立されていない割合が 高かった．技術者評価は重要であり，建設会社では従 業員数が多いほど評価が経営に非常に役立っており, 建設会社に比べ建設コンサルではさらに評価が経営に 役立っている実態が示された.

・2 章の分析より, 技術力の評価の重みに関する項目ご との特徵として, 中小規模ゼネコンではどの項目も年 代順に技術力の評価值が上がっていること，大規模ゼ ネコンで品質管理の技術力はベテランよりは中堅に求 められていること，建設コンサルでは責任感，積極性， 倫理観などの仕事に対する姿勢をどの年代でも共通し て高く評価していることがわかった，今回の調査対象 が愛知県内業者で支店であることに留意は必要である が，国際性は技術者評価の項目として，現状ではあま り着目されていない傾向にあることがわかった．業務 経験年数に着目した分析より, 若手では建設会社の規 模によらず, 工程, 品質, 安全の各管理の技術力が求 められていること, 建設コンサルの若手では, 分析解 析力や企画・改善意識, 説明力, 積極性などがより求 められていることがわかった，さらに建設会社につい ては, 従業員数が多いほど対人的な項目が求められる ことがわかった。

-3 章の分析より，技術者育成の現状について，大規模 ゼネコン, 建設コンサルに比べ, 中小規模ゼネコンで は約半数の企業しか OJTやキャリアパスを制度とし て確立していないことがわかった。
• 4 章の分析より, 企業アンケートの自由回答による技 術者を取り巻く現状と課題については, 内部評価では 日常業務に追われていることからいずれの業態でも評 価が困難であること, 外部評価では発注者の行う施工 成績評価で差異を感じていることがわかった，育成は 土木技術者にとって重要との認識が強く, 社員の特性 をのばすこと, 評価者とのコミュニケーションを行う ことの重要性が示され, 特に中小規模の企業では, 若 手技術者の早期離職が課題であることもわかった. 重 要・必要事項について, 土木技術者の社会的地位の向 上がどの業種・業態でも必要であることがわかった。

\section{(2) 今後の研究の方向}

当初想像していた通り, 中小規模ゼネコンにおける評 価, 育成は遅れている. 経営者たちは必要性を十分認識 していることがわかり，本アンケートに答えることによ って評価項目を確認できたことだけでも十分アンケート の効果が出ているとの感想ももらっている. 今後, 中小 規模ゼネコンの評価, 育成の仕組みづくりの構築に向け 研究を深めていきたい.

アンケートからもわかるように企業独自でできること と, 協会, 団体を通じて自治体との連携も組み込みなが ら全体の育成が重要と考える.

今後は，本研究で明らかにした業種・業態別の技術力 評価の違いを勘案し，企業の業種・業態に見合った評価 指標を作成し，活用方策を考えていく．さらにキャリア パスの概念を経営側に定着させるため, 土木学会中部支 部長特命委員会報告書（中村光）施にあるキャリアパス 事例の具体化に向け研究を深めていく考えである.

謝辞 : 本研究は, 土木学会建設マネジメント研究小委員 会ならびに平成23年度土木学会中部支部調査研究委員会 の活動成果である. 調査に協力頂いた企業, 自治体の関 係者ならびに委員会活動関係者に深く謝意を表する.

\section{参考文献}

1) 土木学会建設マネジメント委員会 技術公務員の役割と責 務研究小委員会 : 技術公務員の役割と責務，2010.

2）野口好夫：自治体技術公務員活用方策に関寸る研究，土 木学会論文集 F4特集号, Vol.66, No.1，2010.

3) 中村光：土木分野における若手人材育成に関する検 討委員会報告書, 土木学会中部支部, 2012.3.

(2012.5.14 受付) 


\section{INVESTIGATION AND ANALYSIS OF EVALUATION AND HUMAN RESOURCE DEVELOPMENT FOR CIVIL ENGINEERS}

\section{Yoshio NOGUCHI, Koji SUZUKI and Chihiro SHIMIZU}

In this study, we conducted the questionnaire for constructors, construction consultants and local governments in order to learn about the current state of evaluation and human recourses development for civil engineers. As a result, it was clarified that smaller constructors don't evaluate their engineers with evaluation items and the items for engineers varies according to the years of experience and industry type. As for human recourses development for civil engineers, it was revealed that half of smaller constructors don't institutionalize OJT and most of them don't tackle both career plan and career path for engineers with a positive attitude. In addition, it was also found that private companies has a high percentage of the support for acquisition of qualifications while the local government has a low percentage of it.. 